\title{
Ekstraksi Informasi Halaman Web Menggunakan Pendekatan Bootstrapping pada Ontology-Based Information Extraction
}

\author{
Erma Susanti*1, Khabib Mustofa ${ }^{2}$ \\ ${ }^{1}$ Program Studi S2/S3 Ilmu Komputer, FMIPA UGM, Yogyakarta \\ ${ }^{2}$ Jurusan Ilmu Komputer dan Elektronika, FMIPA UGM, Yogyakarta \\ e-mail: *11erma.susan@gmail.com, ${ }^{2}$ khabib@ugm.ac.id
}

\begin{abstract}
Abstrak
Ekstraksi informasi merupakan suatu bidang ilmu untuk pengolahan bahasa alami, dengan cara mengubah teks tidak terstruktur menjadi informasi dalam bentuk terstruktur. Berbagai jenis informasi di Internet ditransmisikan secara tidak terstruktur melalui website, menyebabkan munculnya kebutuhan akan suatu teknologi untuk menganalisa teks dan menemukan pengetahuan yang relevan dalam bentuk informasi terstruktur. Contoh informasi tidak terstruktur adalah informasi utama yang ada pada konten halaman web. Bermacam pendekatan untuk ekstraksi informasi telah dikembangkan oleh berbagai peneliti, baik menggunakan metode manual atau otomatis, namun masih perlu ditingkatkan kinerjanya terkait akurasi dan kecepatan ekstraksi. Pada penelitian ini diusulkan suatu penerapan pendekatan ekstraksi informasi dengan mengkombinasikan pendekatan bootstrapping dengan Ontologybased Information Extraction (OBIE). Pendekatan bootstrapping dengan menggunakan sedikit contoh data berlabel, digunakan untuk memimalkan keterlibatan manusia dalam proses ekstraksi informasi, sedangkan penggunakan panduan ontologi untuk mengekstraksi classes (kelas), properties dan instance digunakan untuk menyediakan konten semantik untuk web semantik. Pengkombinasian kedua pendekatan tersebut diharapkan dapat meningkatan kecepatan proses ekstraksi dan akurasi hasil ekstraksi. Studi kasus untuk penerapan sistem ekstraksi informasi menggunakan dataset "LonelyPlanet".
\end{abstract}

Kata kunci-Ekstraksi informasi, ontologi, bootstrapping, Ontology-Based Information Extraction, OBIE, kinerja

\begin{abstract}
Information extraction is a field study of natural language processing by converting unstructured text into structured information. Several types of information on the Internet is transmitted through unstructured information via websites, led to emergence of the need a technology to analyze text and found relevant knowledge into structured information. For example of unstructured information is existing main information on the content of web pages. Various approaches for information extraction have been developed by many researchers, either using manual or automatic method, but still need to be improved performance related accuracy and speed of extraction. This research proposed an approach of information extraction that combines bootstrapping approach with Ontology-Based Information Extraction (OBIE). Bootstrapping approach using small seed of labelled data, is used to minimize human intervention on information extraction process, while the use of guide ontology for extracting classes, properties and instances, using for provide semantic content for semantic web. Combining both approaches expected to increase speed of extraction process and accuracy of extraction results. Case study to apply information extraction system using "LonelyPlanet" datasets.
\end{abstract}

Keywords - Information extraction, ontology, bootstrapping, Ontology-Based Information Extraction, OBIE, performance 


\section{PENDAHULUAN}

$P^{2}$ ertumbuhan jumlah web di Internet berdasarkan survey dari [1] menunjukkan peningkatan pesat dari 18 juta pada tahun 2000 menjadi 716 juta web pada tahun 2013. Berbagai jenis informasi di Internet ditransmisikan secara tidak terstuktur menyebabkan munculnya kebutuhan akan suatu teknologi ekstraksi informasi untuk menganalisa teks dan menemukan pengetahuan yang relevan dalam bentuk informasi terstruktur. Ekstraksi informasi bertujuan untuk mengekstraksi sekumpulan data teks untuk mendapatkan "fakta-fakta berkaitan dengan kejadian (events), entitas, atau keterhubungan (relationship)" dalam bentuk informasi terstruktur sebagai masukan untuk basis data [2].

Pendekatan yang dapat digunakan untuk membangun sistem ekstraksi informasi menurut [3] dibagi menjadi dua, yaitu knowledge engineering dan automatic training. Pendekatan knowledge engineering atau rule-based menggunakan komponen berupa grammar/rules yang ditulis secara manual oleh knowledge engineer (pakar). Sedangkan, pada pendekatan automatic training atau machine learning, pembentukan rules dilakukan secara otomatis dengan mempelajari dari data latih yang ada. Pendekatan automatic training secara umum diaplikasikan menggunakan algoritma klasifikasi, contohnya menggunakan Support Vector Machine (SVM) atau Conditional Random Field (CRF) [4].

Kelebihan dari pendekatan knowledge engineering menurut [3] adalah pada kinerja yang baik karena rules dituliskan secara manual oleh pakar sehingga hasilnya lebih akurat dan tidak diperlukan data latih. Kekurangannya terletak pada proses pengembangannya yang sangat menyulitkan karena memerlukan banyak tenaga, sulit untuk dilakukan perubahan spesifikasi setelah sistem jadi, dan juga perlu tersedianya orang yang ahli dalam membuat rules. Selain itu, rules dapat berjalan lambat dan proses pengembangannya memakan waktu yang lama [5]. Ketersediaan sistem yang dapat mengekstraksi informasi secara otomatis akan sangat membantu proses ekstraksi informasi. Otomatisasi ekstraksi informasi dapat dilakukan dengan menggunakan pendekatan machine learning. Proses pengembangannya tidak memerlukan banyak waktu, namun diperlukan ketersediaan data latih yang besar [4]. Permasalahan lainnya adalah terkait dengan penyediaan konten semantik untuk web semantik [6].

Penggunaan ontologi sebagai panduan untuk ekstraksi informasi disebut sebagai Ontology-Based Information Extraction (OBIE), dikembangkan oleh [6] merupakan pendekatan ekstraksi informasi yang memanfaatkan ontologi sebagai panduan untuk mengekstraksi informasi dari dokumen. Permasalahan pada pendekatan tersebut adalah perlunya suatu semantik leksikon (kamus kata atau kosa kata) untuk domain spesifik data yang diekstraksi. Oleh karena itu, pendekatan bootstrapping menggunakan sedikit contoh data berlabel, diusulkan untuk mengatasi permasalahan tersebut. Penggunaan pendekatan bootstrapping dilakukan untuk meminimalkan campur tangan manusia dalam pembentukan pengetahuan [7]. Pada penelitian ini diusulkan pendekatan bootstrapping dan Ontology-Based Information Extraction untuk mengekstraksi informasi dari sumber halaman web. Pengkombinasian kedua pendekatan tersebut diharapkan dapat meningkatkan akurasi hasil ekstraksi dan kecepatan proses ekstraksi informasi.

\section{METODE PENELITIAN}

Penelitian dimulai dengan memilih teks korpus dan domain ontologi yang relevan dengan jenis informasi yang diekstraksi. Teks korpus merupakan kumpulan teks dari koleksi halaman web yang akan dijadikan sebagai masukan pada proses ekstraksi. Sistem OBIE akan dikembangkan menggunakan metode extraction rules (aturan ekstraksi) dan gazeetter list (daftar kamus).

IJCCS Vol. 9, No. 2, July 2015 : $111-120$ 


\subsection{Deskripsi Sistem}

Sistem diawali dengan proses pelatihan menggunakan pendekatan bootstrapping untuk mengekstraksi informasi berkaitan dengan konsep. Proses pelatihan ini diperlukan untuk pembentukan extraction rules dan daftar kamus. Extraction rules dan daftar kamus akan digunakan sebagai komponen untuk sistem OBIE. Selanjutnya sistem OBIE diimplementasikan menggunakan framework GATE (General Architecture for Text Engineering) [8]. Extraction rules ditulis ke dalam format yang diketahui sebagai Java Annotation Pattern Engine (JAPE) sebagai komponen GATE. Penggunaan studi kasus digunakan untuk menunjukkan penggunaan dari sistem ekstraksi informasi yang diteliti dan untuk mengetahui hasil evaluasi dari penerapan pendekatan yang digunakan untuk ekstraksi informasi. Setelah proses ekstraksi selesai, dilakukan pengujian evaluasi untuk mengetahui kinerja sistem, terkait nilai precision, recall, $F$ measure dan kecepatan waktu ekstraksi. Selanjutnya berdasarkan hasil evaluasi yang diperoleh, dilakukan perbandingan kinerja ekstraksi informasi dengan penelitian terdahulu.

\section{2 Arsitektur Sistem}

Arsitektur sistem ekstraksi informasi pada penelitian ini merupakan adaptasi dari arsitektur umum sistem ekstraksi informasi dari [9] dan arsitektur umum sistem OBIE dari [6]. Masukan sistem ekstraksi informasi berupa teks bahasa alami (natural language text) tidak terstruktur dari sumber teks pada halaman web (teks HTML). Proses ekstraksi informasi sesuai dengan konsep OBIE akan melibatkan ontologi sebagai panduan ekstraksi dan menghasilkan keluaran berupa informasi terekstraksi yang direpresentasikan dalam bentuk XML dan teks teranotasi. Proses ekstraksi yang dipandu oleh ontologi akan mengekstraksi sesuatu (things) seperti kelas (classes), properties, dan instance. Selanjutnya dilakukan pengujian evaluasi kinerja dari sistem ekstraksi informasi menggunakan parameter pengukuran precision, recall, $F$ measure, dan kecepatan.

Arsitektur sistem ekstraksi informasi pada penelitian ini dibagi menjadi tiga fase yaitu fase pelatihan, fase pengembangan dan fase evaluasi. Pada fase pelatihan, sistem mengidentifikasi pola (patern) dan daftar kamus (disebut dengan semantik leksikon), yang dipelajari menggunakan pendekatan bootstrapping. Sebelumnya, korpus harus melewati tahapan preprocessing sebelum proses pelatihan. Tujuan dari fase pelatihan adalah untuk menghasilkan pattern dan semantik leksikon. Pada fase pengembangan merupakan fase untuk mengidentifikasi dan mengklasifikasi informasi yang relevan pada kumpulan teks baru. Teks yang digunakan tersebut tidak termasuk dalam korpus pada proses pelatihan. Patern di-generate untuk mendapatkan extraction rules. Pada fase pengembangan, teks masukan dilewatkan ke sistem OBIE untuk menghasilkan suatu keluaran. Fase terakhir adalah fase evaluasi atau pengujian. Arsitektur sistem OBIE pada penelitian ini dapat dilihat pada Gambar 1.

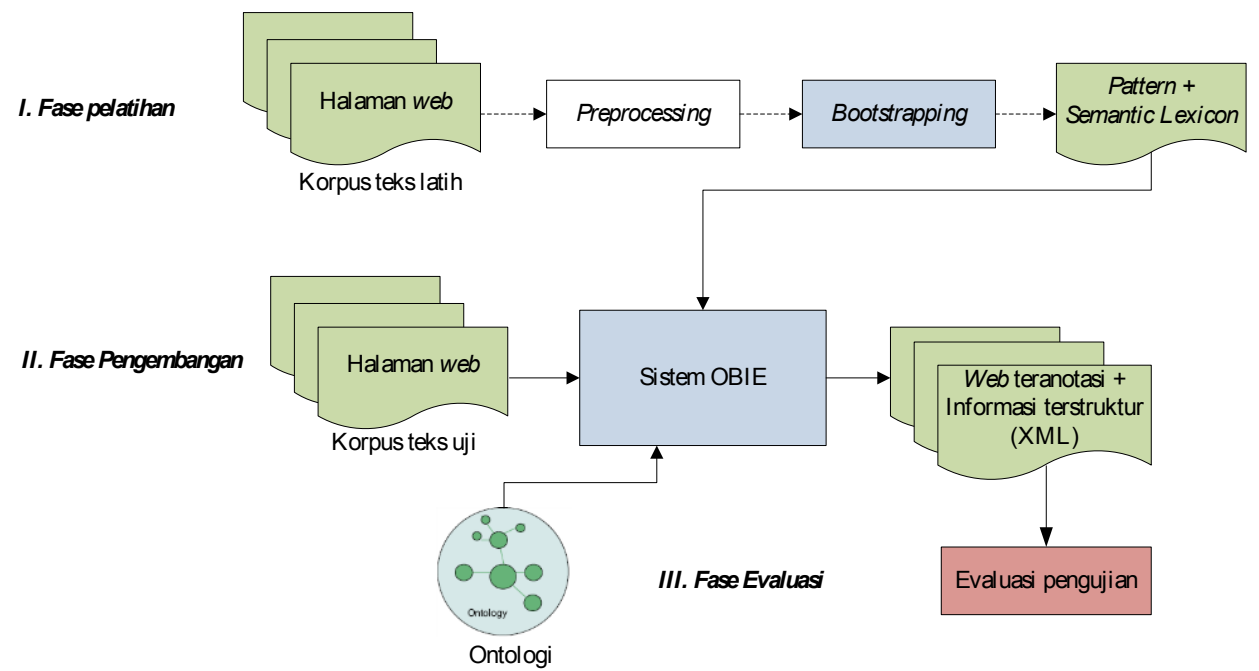

Gambar 1 Arsitektur sistem ekstraksi informasi 


\subsubsection{Preprocessing}

Tahap awal dari ekstraksi informasi adalah dengan melakukan preprocessing pada masukan teks yang bertujuan untuk mempersiapkan teks menjadi data yang dapat diproses sebagai masukan sistem ekstraksi informasi. Proses parsing dilakukan pada semua dokumen teks untuk mengidentifikasi semua kata benda (noun) atau frasa kata benda (noun phrase/NP) dan konteksnya.

Proses parsing dalam preprocessing terdiri dari deteksi kalimat (sentence detection), pemotongah kalimat menjadi token atau kata (tokenization), pemberian sintaksis informasi (POS tagging), dan pemotongan frasa (NP chunker). Setelah parsing teks selesai, selanjutnya dilakukan proses indexing dan filtering. Proses indexing kalimat dilakukan dengan mendeteksi kata/frasa NP dalam kalimat, token di sebelah kiri NP dan token di sebelah kanan NP. Setelah proses indexing selasai, maka keluaran (disebut document-set) disimpan ke dalam basis data untuk diproses dalam proses bootstrapping. Sebelum diproses dalam algoritma bootstrapping, document-set perlu difiltering dengan membuang kata/frasa NP yang tidak akan menghasilkan ekstraksi. Contoh document-set yang perlu untuk dilakukan filtering yaitu kata benda yang mengandung angka, karena angka tidak akan mengekstraksi entitas nama. Proses indexing terhadap token dari window kiri dan kanan NP memanfaatkan query dalam Lucene Based Search (terintegrasi dalam GATE) untuk mendapatkan konteks yang dapat digunakan sebagai masukan dalam bootstrapping.

\section{2.2 Bootstrapping}

lain:

Tahapan ekstraksi menggunakan algoritma bootstrapping langkah-langkahnya antara

1. Mulai dengan sejumlah kecil seed (contoh) yang diambil dari instance pada ontologi panduan.

2. Masukkan jumlah iterasi yang akan dilakukan.

3. Cocokkan seed dengan document-set dari korpus teks yang telah di-preprocessing untuk mendapatkan kemunculan term (occurrence) dan pattern extraction.

4. Hitung skor untuk pattern extraction berdasarkan kemunculan occurrence dan documentset.

5. Aplikasikan pattern extraction dengan skor terbaik pada seluruh document-set dan catat hasil ekstraksi sebagai anggota kandidat leksikon.

6. Hitung skor untuk kandidat leksikon berdasar pada jumlah pattern yang berhasil melakukan ekstraksi.

7. Tambahkan kandidat seed baru terbaik ke dalam leksikon dan gunakan sebagai seed pada iterasi berikutnya.

8. Kembali ke langkah tiga. Berhenti jika proses sudah tidak dapat menghasilkan pattern dan seed baru, atau berhenti jika iterasi telah mencapai maksimum.

\subsubsection{Ontology-Based Information Extraction}

Rancangan diagram alir proses pengembangan sistem dijalankan sebagai pipeline proses. Prosesnya dilakukan secara berurutan. Selesai proses yang satu, baru dapat beralih ke proses berikutnya. Pertama korpus teks masukan diproses ke dalam modul preprocessing untuk menghasilkan format masukan yang dapat diterima oleh proses Ontology Lookup. Hasil dari proses tersebut kemudian diolah dalam modul OBIE untuk dapat dilakukan proses populasi ontologi. Proses populasi pada ekstraksi informasi dengan panduan ontologi digambarkan sebagai proses untuk mendapatkan dan menghubungkan entitas yang ada dalam teks dengan classes, properties, atau instance pada ontologi (lihat Gambar 2).

IJCCS Vol. 9, No. 2, July 2015 : $111-120$ 


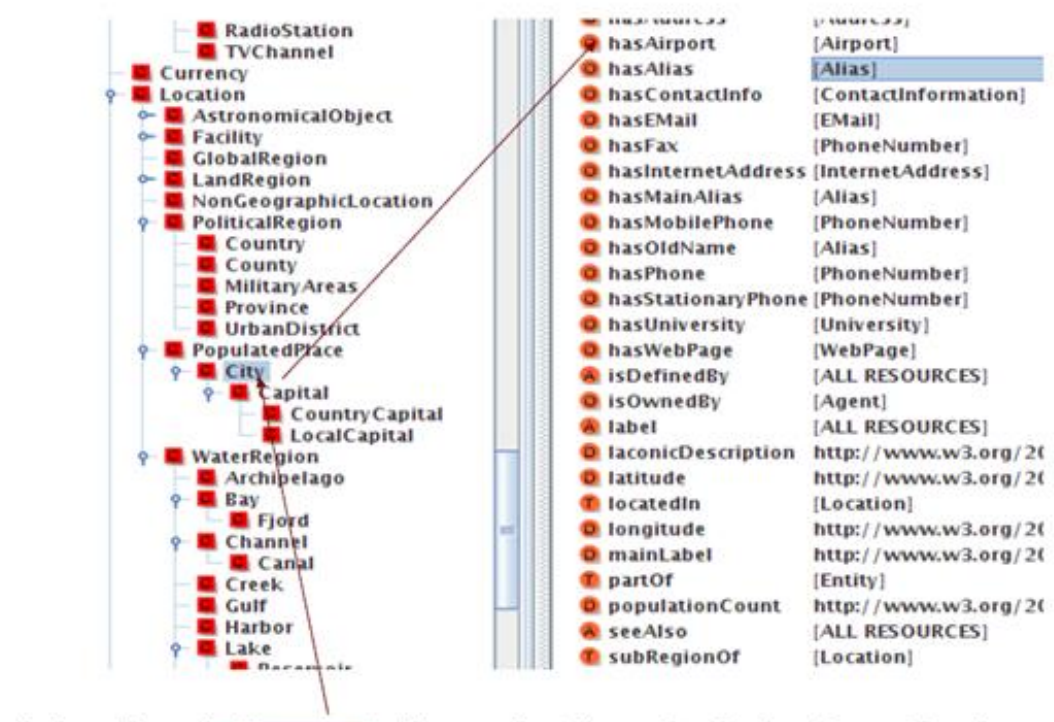

John lives in London. He works there for Polar Bear Design.

Gambar 2 Proses populasi ontologi

Detail rancangan sistem OBIE akan menggunakan Ontology-based Gazetteer pada GATE. GATE akan dikoneksikan dengan OWLIM untuk membaca domain ontologi dan menyimpan hasil. Domain ontologi dimuat ke dalam GATE, teks dianotasi sesuai dengan kemunculan instance dalam teks dan nilai property. Komponen ekstraksi informasi akan menggunakan komponen bahasa (Language Resource/LR) yang terdiri dari ontologi panduan dan korpus dokumen untuk ekstraksi teks. Korpus teks berupa halaman web akan diproses sebagai masukan dalam aplikasi OntoRoot.

Komponen pemrosesan (Processing Resource/PR) pada sistem OBIE ditunjukkan pada Gambar 3 terdiri dari komponen Tokenizer, Sentence Splitter, POS Tagger, dan Morpher. Hasil pemrosesan berupa anotasi dengan fitur sesuai dengan gazetteer pada ontologi. Selanjutnya hasil proses ekstraksi di-export kedalam format XML. Keluaran dari proses tersebut adalah berupa web teranotasi dan XML.

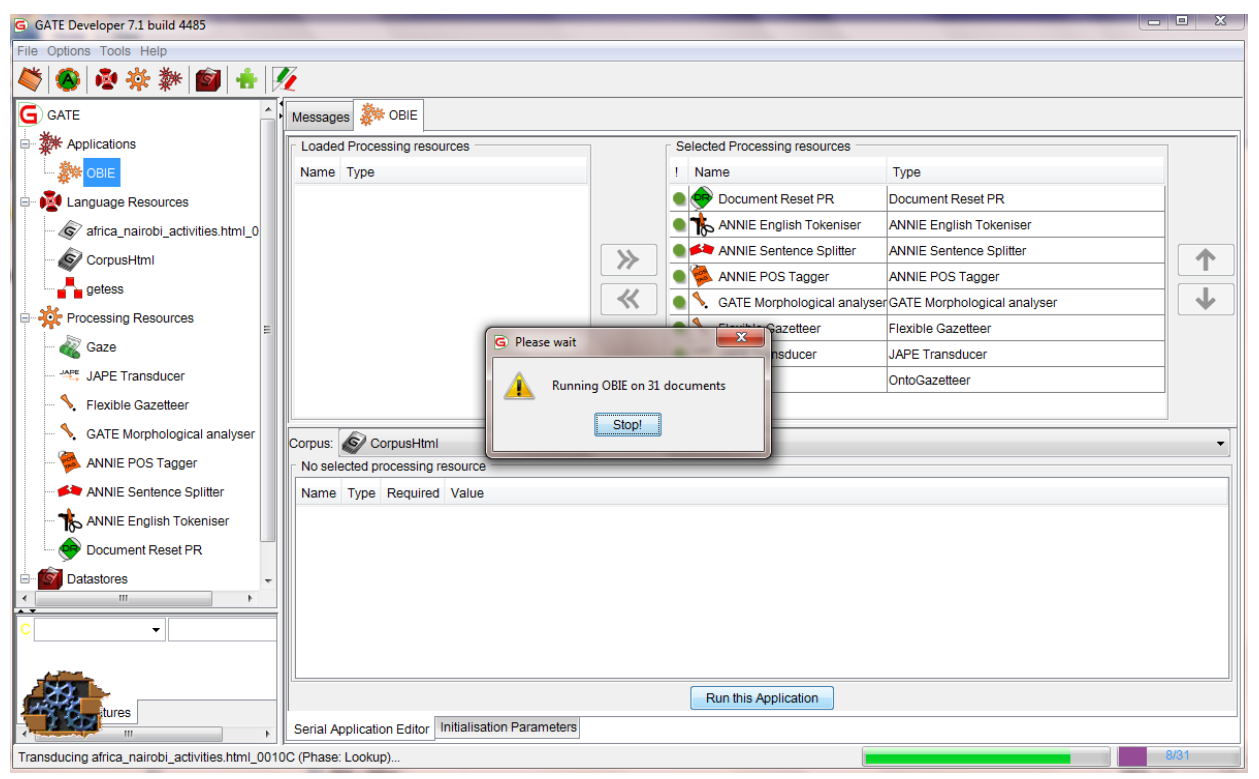

Gambar 3 Komponen pemrosesan pada sistem OBIE 


\subsubsection{Pengukuran Kinerja}

Pengukuran evaluasi kinerja ekstraksi informasi didefinisikan sebagai pengukuran kinerja sistem ekstraksi informasi dibandingkan dengan human-annotated gold standard. Pengukuran evaluasi kinerja sistem ekstraksi informasi dapat menggunakan model pengukuran kuantitatif. Pengukuran kuantitatif ini terkait dengan perhitungan hasil keluaran yang diberikan oleh sistem dibandingkan dengan hasil yang seharusnya dikeluarkan oleh sistem. Evaluasi pengukuran hasil ekstraksi informasi disini menggunakan perbandingan hasil ekstraksi informasi dengan evaluasi gold standard.

Model pengukuran evaluasi ekstraksi informasi mengadopsi model pengukuran untuk tugas klasifikasi teks yaitu menggunakan precision dan recall. Perbandingan dua pengklasifikasi (classifiers) menggunakan nilai pengukuran tunggal $F$-measure, yang merupakan kombinasi nilai precision dan recall [9]. Parameter-parameter tersebut digunakan untuk mengetahui kinerja tingkat keberhasilan sistem ekstraksi informasi yang dikembangkan. Persamaan untuk hitung precision $(P)$, recall $(R), F$-measure dan kecepatan $(K e c)$ dapat dilihat pada persamaan (1), (2), (3), dan (4).

$$
\begin{gathered}
P=\frac{T P}{T P+F P} \\
R=\frac{T P}{T P+F N} \\
F-\text { measure }=\frac{2 P R}{P+R} \\
\text { Kec }=\frac{\text { JumlahDok }}{\text { Waktu }}
\end{gathered}
$$

Dimana:

TP $\quad=$ jumlah dokumen relevan yang ditemukan (true positive).

FP $\quad=$ jumlah dokumen tidak relevan yang ditemukan (false positive).

FN $\quad=$ jumlah dokumen tidak relevan dan tidak ditemukan (false negative).

JumlahDok $\quad=$ jumlah dokumen ekstraksi.

\subsubsection{Evaluasi Pengujian}

Korpus teks untuk pelatihan dan pengujian menggunakan dataset "LonelyPlanet" dari penelitian [8]. Dataset ini juga telah digunakan sebagai benchmark pada penelitian [10]. Motivasi pemilihan dataset tersebut sebagai benchmark karena penggunaan dataset secara umum digunakan pada penelitian ekstraksi informasi sehingga hasil dari metode yang digunakan dapat secara langsung dibandingkan dengan hasil dari metode lain. Dataset "LonelyPlanet" (LP) dijelaskan dalam penelitian [11] merupakan korpus dalam domain $e$ tourism, berisi kumpulan teks bahasa alami (natural language text) berbahasa Inggris yang terdiri dari 1801 file html yang dikoleksi dari situs http://www.lonelyplanet.com. Dataset LP berisi kumpulan halaman web tentang deskripsi tujuan wisata dari berbagai negara di dunia. Korpus tesebut dipilih karena artikel di dalamnya memuat informasi yang terkait dengan target informasi yang akan diekstraksi.

\section{HASIL DAN PEMBAHASAN}

Hasil dari fase pelatihan mengunakan algoritma bootstrapping telah dilakukan sebanyak 25 iterasi menggunakan data latih 1771 file teks (HTML) dan 5 seed (contoh term) awal menghasilkan kemunculan term (occurrence), pattern, dan term baru. Hasil yang diperoleh seperti terlihat pada Gambar 4 menunjukkan kecenderungan bahwa jumlah ekstraksi mengalami

IJCCS Vol. 9, No. 2, July 2015 : $111-120$ 
peningkatan pada setiap penambahan iterasi. Sedangkan, pada Gambar 5 menunjukkan bahwa dari hasil term keseluruhan yang dapat diekstraksi hanya sebagian kecil term saja yang dapat digunakan.

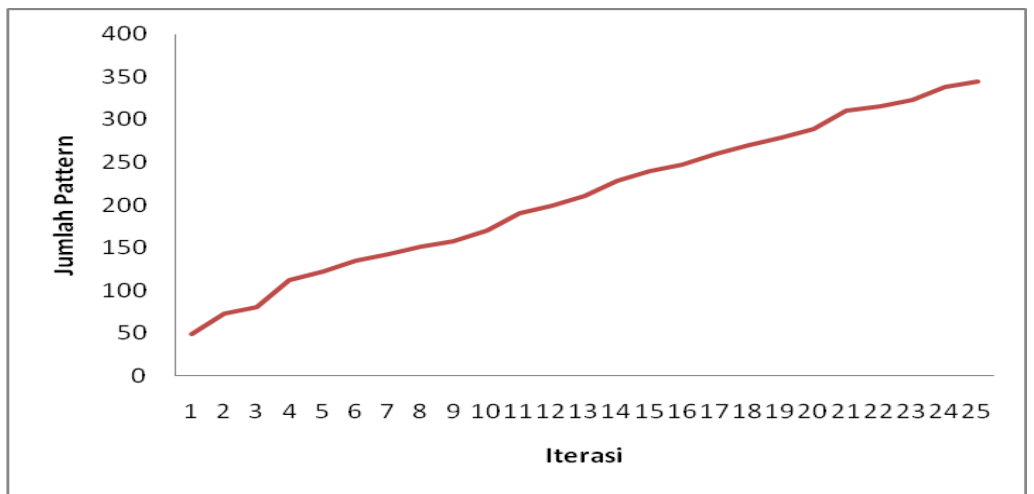

Gambar 4 Grafik pengaruh jumlah iterasi terhadap jumlah pattern

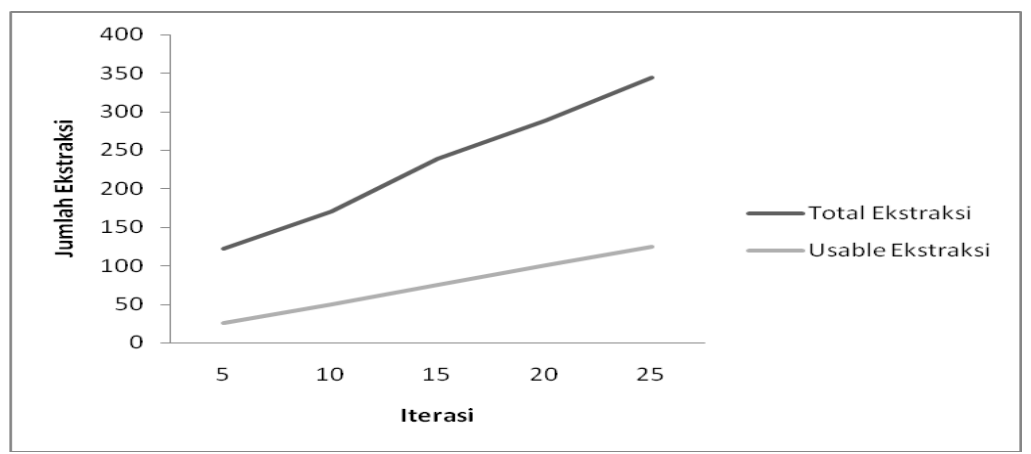

Gambar 5 Grafik pengaruh jumlah iterasi terhadap jumlah ekstraksi dan penggunaan ekstraksi

Hasil dari fase pengembangan sistem OBIE berupa teks yang telah dianotasi berdasarkan classes, properties, instance pada ontologi panduan. Hasil anotasi dengan OAT (Ontology Annotation Tools) GATE dapat dilihat pada Gambar 6.

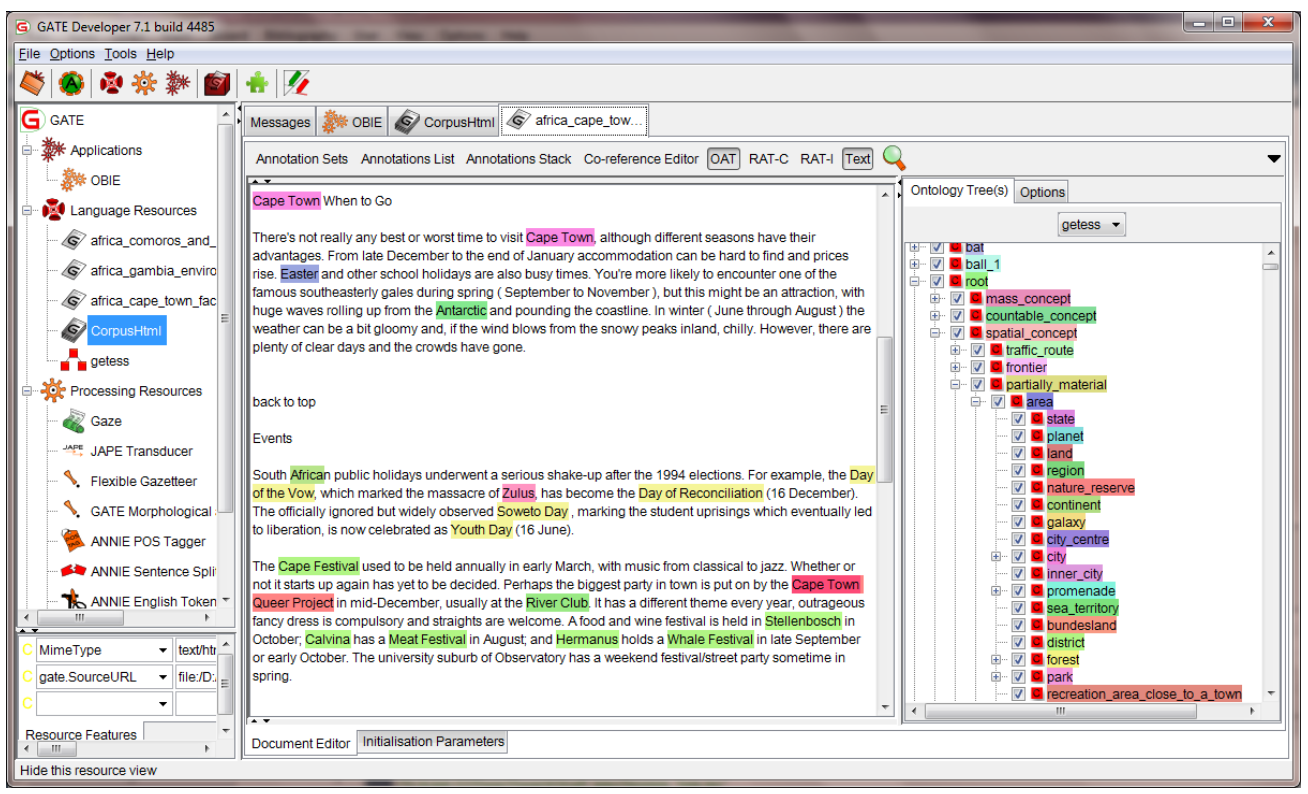

Gambar 6 Hasil anotasi dengan OAT 
Hasil proses populasi ontology dengan Ontology Lookup pada korpus ditunjukkan pada Gambar 7. Keterangan tipe anotasi dapat dilihat pada bagian tengah bawah pada jendela aplikasi.

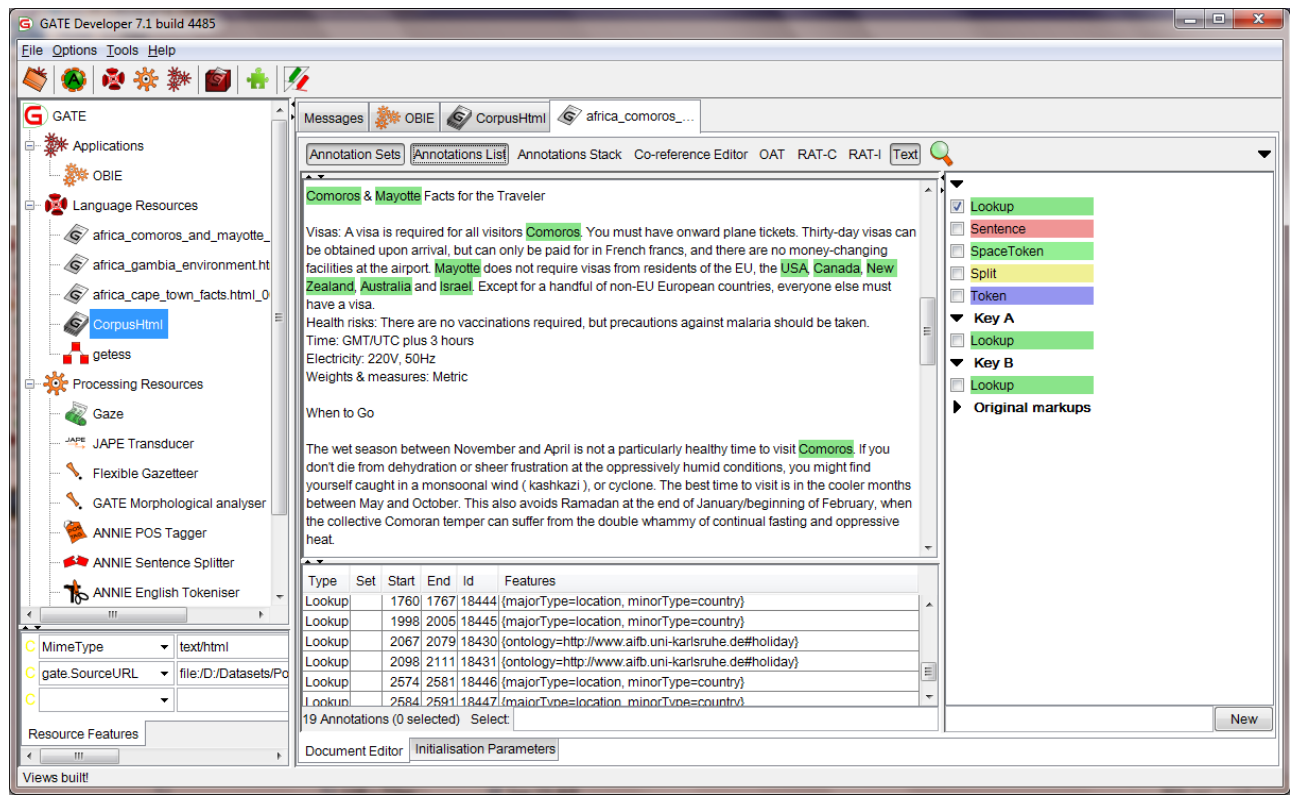

Gambar 7 Hasil populasi ontologi

Hasil pengujian ekstraksi informasi untuk mendapatkan entitas baru dari teks (Named Entity Recognition / NER) menggunakan 30 dataset uji dilakukan dengan membandingkan dengan hasil anotasi gold standard dari dataset yang ada. Hasil rata-rata pengujian sistem OBIE dan perbandingan dengan hasil dari penelitian lain disajikan pada Tabel 1. Sedangkan perbandingan kecepatan proses sistem OBIE dengan sistem ekstraksi lain yang tidak menggunakan ontologi dapat dilihat pada Tabel 2.

Tabel 1 Perbandingan beberapa sistem ekstraksi informasi

\begin{tabular}{|c|c|c|c|}
\hline Evaluasi Kinerja (\%) & Penelitian [11] & Penelitian [10] & Penelitian ini (OBIE) \\
\hline Precision & 29,33 & 67,37 & 73 \\
\hline Recall & 65,49 & 85,13 & 62 \\
\hline F-measure & 40,52 & 75,21 & 67 \\
\hline
\end{tabular}

Perbandingan dengan penelitian [10] memperlihatkan bahwa nilai precision pada penelitian ini lebih tinggi dari pada nilai recall, sebaliknya pada penelitian [10] nilai recall-nya lebih tinggi daripada nilai precision. Hasil kinerja secara keseluruhan dapat dilihat pada nilai $F$ measure. Hasil perbandingan menunjukkan bahwa sistem OBIE memiliki kecenderungan yang meningkat bila dibandingkan dengan penelitian [11], namun cenderung menurun bila dibandingkan dengan penelitian [10].

Tabel 2 Perbandingan kecepatan proses pada beberapa sistem ekstraksi informasi

\begin{tabular}{|c|c|}
\hline Sistem Ekstraksi Informasi & Kecepatan rata-rata (dokumen/detik) \\
\hline OBIE & 0,61433 \\
\hline ANNIE & 0,608845 \\
\hline LingPipe IE Systems & 1,049218333 \\
\hline
\end{tabular}


Kecepatan rata-rata sistem OBIE menunjukkan waktu pemrosesan yang tidak jauh berbeda bila dibandingkan dengan sistem ANNIE. Sedangkan bila dibandingkan dengan LingPipe IE Systems waktu prosesnya cenderung lebih cepat.

\section{KESIMPULAN}

Berdasarkan hasil uji coba yang telah dilakukan, dapat disimpulkan bahwa:

1. Hasil uji coba ekstraksi informasi ekstraksi informasi menggunakan dataset "LonelyPlanet" menunjukkan kinerja yang cenderung meningkat jika dibandingkan dengan penelitian [11]. Hasil evaluasi pengujian sistem didapatkan precision $73 \%$, recall $62 \%$ dan F-measure $67 \%$.

2. Hasil uji terhadap lama waktu yang diperlukan dalam pemrosesan 30 dokumen teks untuk sistem OBIE menunjukkan kecenderungan waktu proses yang hampir sama dengan sistem ANNIE. Sedangkan waktu proses sistem OBIE terhadap sistem LingPipe memiliki kecenderungan dapat memproses dokumen lebih cepat.

3. Proses iterasi pada algoritma bootstrapping untuk ekstraksi pattern menunjukkan bahwa jumlah extraction pattern yang didapatkan berbanding lurus dengan jumlah iterasi.

4. Jumlah term hasil ekstraksi yang dapat digunakan pada setiap iterasi bootstrapping menunjukkan hanya sebagian kecil saja yang dapat digunakan dari keseluruhan total term yang dapat diekstraksi.

\section{SARAN}

Sistem ekstraksi informasi pada penelitian ini masih perlu ditingkatkan lagi kinerja terkait nilai precision dan recall-nya, sehingga pemrosesan ekstraksi informasi menjadi lebih efektif. Penemuan teknik ekstraksi informasi baru yang dapat diintegrasikan dengan sistem OBIE dapat berperan untuk proses ini. Hal ini karena sistem ekstraksi informasi menggunakan panduan ontologi merupakan pendekatan ekstraksi informasi yang relevan dengan kondisi saat ini, dapat diintegrasikan dengan web semantik untuk menyediakan konten semantik untuk web semantik.

\section{DAFTAR PUSTAKA}

[1] Netcraft, 2013, August 2013 Web Server Survey, http://news.netcraft.com/archieves/2013/08/09/august-2013-web-server-survey.html, diakses tgl 1 Desember 2013.

[2] Piskorski, J., dan Yangarber, R., 2013, Information Extraction: Past, Present and Future, Poibeau, T. (ed): Multi-source, Multilingual Information Extraction and Summarization, Ch. 2, Springer-Verlag, Berlin.

[3] Appelt, D. E, 1999, Introduction to Information Extraction. AI Communications, No.3, Vol.12, 161-172.

[4] Labsky, M., 2008, Information Extraction from Websites using Extraction Ontologies, Tesis, University of Economic Prague. 
[5] Maynard, D., Li, Y., dan Peters, W., 2007, NLP Techniques for Term Extraction and Ontology Population, Buitelaar, P. dan Cimiano, P. (ed): Bridging the Gap between Text and Knowledge-Selected Contributions to Ontology Learning and Population from Text, IOS Press.

[6] Wimalasuriya, D. C, and Dou, D. , 2009, Ontology-Based Information Extraction: An Introduction and a Survey of Current Approach, Journal of Information Science, vol XX, hal 1-20.

[7] Huang, R, and Riloff, E, 2012, Bootstrapped Training of Event Extraction Classifiers, Proceeding of 13th Conference of the European Chapter of the Association for Computational Linguistics.

[8] Cunningham, H., 2002, GATE, A General Architecture of Text Engineering, Computers and the Humanities, vol 36, hal 223-254.

[9] Moens, M., 2006, Information Extraction: Algorithms and Prospects in a Retrieval, Springer, Netherland.

[10] Rios-Alvarado, A. B, Lopez-Arevalo, I., and Sosa-Sosa, V. J., 2013, Learning Concept Hierarchies from Textual Resources for Ontologies Construction, Expert Systems with Applications, vol 40, hal 5907-5915.

[11] Cimiano, P., Hotho, A., and Staab, S. , 2005, Learning concept hierarchies from text corpora using formal concept analysis, Journal of Artificial Intelligence Research, vol 24, hal 305-339. 